\title{
The People Who Are Never Lost
}

\author{
Family Trees in a Political Context \\ in Present Day Bashkortostan
}

\author{
Boglárka Mácsai \\ Research Institute for Linguistics, Hungarian Academy of Sciences, Budapest
}

\begin{abstract}
The study seeks to find an answer to the issue of how a revived tradition can serve political interests that are simultaneously attempting to satisfy the demands of ethnicity-based Bashkir nation-building and the demands of affiliation with the larger multi-ethnic nation of the Russian Federation. The core of the analysis is centered around the political contextualizing of the program called 'Holiday of Family-Tree' as well as the instrumentalist interpretation of local special literature and methodology related to the program. The paper, on the one hand, scrutinizes the family-tree research as a Bashkir tradition, which supports the power and autonomy of the Bashkir nation through the Bashkirisation of Tatars living in the north-western areas. On the other hand, it highlights how this ethnic tradition is adjusted to the traditions of the Russian local history research (kraevedenie) and thus, how it legitimates symbolically the role of the Bashkir nation in the multi-ethnic nation of the Russian Federation.
\end{abstract}

Keywords: Bashkortostan, Bashkir, Tatar, Bashkirisation, family tree, local history, ethnicity, nationalism, political anthropology

"Just as the mighty and wild river gains strength from a tiny stream, so is our republic enriched by families and clans." Amina Ivnievna Šafikova, Minister of Culture in the Republic of Bashkortostan, Karmaskaly District, Family Tree Celebration, September 23, 2013.

Following the collapse of the Soviet Union (1991) the central powers allowed considerable freedom, albeit within a controlled framework, not only for the modern appearance of national folklore, which had already begun to flourish during the Soviet period, but also for the revitalisation and practice of various religions and other traditions that may have been previously forbidden. These conditions enabled a more tangible manifestation of ethnic identities as well as the reinforcement of cultural autonomy among individual groups. As to which traditions gain prominence in the case of which ethnic groups, this is largely determined by the culture of the given group, its territory, and its administrative, legal and political status within the Russian Federation, but also by the culture of neighbouring groups and the nature of interethnic relations. 
In the case of the Volga republics discussed here, ${ }^{1}$ in the Udmurt Republic, for example, efforts made by the Udmurt Ortodox majority primarily aim to foster the everyday use of minority language and culture. Udmurt language gastro and erotic blogs, ethno futuristic fashion events parading modernised versions of traditional folk dress, street art promoting notable Udmurt poets and the second place prize awarded to Buranovskie Babuški at the Eurovision Song Festival in 2012 have all been attempts to reinterpret and pass on Udmurt language and culture. While there are those in the Udmurt Republic who have returned to the original Udmurt religion, its presentation as symbol of ethnicity is more typical of unbaptised practitioners of the Udmurt faith living in neighbouring Bashkortostan, trans-Kama Udmurts, who are known for their continuous practice. Socalled national prayer (rasken' ozks) performs a similar function in the life of Erzya Mordvins as it does in the religion of those living in the Mari Republic (KNORRE 2008; KNORRE - KONSTANTINOva 2010). A return to what is regarded as an ancient, original and uniquely ethnic religious practice provides an opportunity for a distinct separation from neighbouring ethnic groups who practice Islam and is a policy of identity that promotes strong cohesion and unity among various groups.

By contrast, in Tatarstan, which is struggling for both cultural and political autonomy, religious overtones merely serve to colour far-right movements ${ }^{2}$ as Islam is not regarded as a typically Tatar ethnic religion. Here, the alignment of Tatar history and ethnography in opposition to Russians, and in some cases Bashkirs, is a far more decisive symbolic element in politics, in which a glorious historical past and the political legacy of the Kazan Khanate are what predestine the Tatar nation to realise its autonomy (GoRENBURG 2004:12-18).

Given its place on this colourful palette, it has not been easy for Bashkortostan to find its own ethnic symbol. The religion, culture and language of the Bashkir people are very closely related to those of neighbouring Tatars, and so none of these have proven suitable as ethnic markers since political strategies for promoting national identity are usually characterised by distinct boundaries drawn in opposition to other identities. Bashkir society and its political elite have found another tool for the reinforcement of national identity by revitalising a tradition that succeeds in expressing a strong separation while melding smoothly with certain Russian traditions. The national genealogical research program does not simply encourage, but in fact makes compulsory the practice of what is regarded as an ancient Bashkir custom while also satisfying a commitment to Soviet and Russian moral education (vospitanie) in the context of research on local history. This duplicity is especially important in Bashkir politics, which swings on the line between nationalism and Russian-friendly policies, making it possible to simultaneously reinforce both political independence and loyalty. The encouragement of genealogical research therefore manages to fully serve practically every Bashkir political goal. Based on an analysis of the political context, professional ethnographic literature used in the

\footnotetext{
${ }^{1}$ Based on their proximity, their similar historical pasts and their close interethnic relations as well as their administrative status, it is possible to classify these Volga republics in one group as a basis for comparison, including: the Udmurt Republic, the Mari-El Republic, Chuvashia, the Mordvin Republic, and the republics of Tatarstan and Bashkortostan.

${ }^{2}$ Not counting the "muslimisation" of Christian Tatars, which the Tatar political elite has attempted to achieve as a way of increasing and retaining the Tatar majority.
} 
development of the program and the history of local historical research in Russia, the aim of this study is demonstrate how the Bashkir genealogical research program helps to support this multifaceted policy. ${ }^{3}$

\section{"PERSPECTIVES ON THE WORLD" THEORIES OF ETHNICITY}

Local perspective and public thinking with regards to Bashkir ethnicity are significantly determined by the primordialist theories of ethnicity in Soviet ethnography. These cannot be ignored in a discussion of Family Tree celebrations since the related works of ethnographic literature also played an important role in determining the basic principles and methodology of genealogical research. The most important among these was research conducted by historian-ethnographer Rail Kuzeev (1929-2005), which dealt with the study, categorisation and care of still traceable genealogical depictions. Kuzeev regarded family trees as a more or less reliable historic source, a genealogical chronicle (genealogičeskâ̂ letopis'), implying the ethnogenesis so important to Bashkir history and Russian schools of thought. The centre of interest in Soviet ethnography was the study and primordialist analysis of ethnos, meaning a well-defined unit with its own culture, language and "character", and research on ethnogenesis i.e. the birth and development of ethnos. Analysis of inner identity, its modes of construction and ethnic boundary building mechanisms was alien to the Soviet academic mentality, and so ethnicity was also interpreted as a rigid category which at most could undergo either consolidation or assimilation. Methodology was based on morphological, functional, historical and typological analyses, which set a narrow and inflexible framework for Soviet ethnographical research (GumiLJov 1975; BromLej 1976; FilipPov 2010). These methodological principles were pervasive in Kuzeev's analyses and terminology, the unchanged use of which demands some explanation.

Following in Kuzeev's footsteps, most Bashkir researchers and those in Bashkortostan dealing with the subject apply the terminology used by Kuzeev and the Soviet school of thought, and this is also common to discourse in connection with Family Tree celebrations. My goal is not to engage in an analytical critique of works dealing with Bashkir ethnic processes, but to provide an understanding of the use of genealogical research for political aims. Therefore, my study will make use of the original terminology and analyses (such as ethnos, ethnogenesis, and later tribe), knowing that these may not be valid or suitable for my own research position. At the same time, usage of these terms is absolutely necessary since it is only via the categories defined by Soviet ethnography that it is possible to understand the mentality adopted by the current political course, which presents Bashkir family trees as an ethnic symbol and the Bashkir nation as a coherent unit. In other words, I am interpreting Kuzeev's works as a kind of emic text,

\footnotetext{
${ }^{3}$ The research has been made possible by the support of TÁMOP-4.2.4.A/2-11/1-2012-0001 Young Researcher Scholarship for Hungarian and International Researchers in Convergence Regions of the National Program of Excellence (NKP). The project was coo-funded by the European Union and the European Social Fund. The research was also part of the Hungarian Scientific Research Fund (OTKA) no 57093 project titled "Symbolic landscapes and ethnic relations in post-Soviet Russia".
} 
which is an integral part of the celebration's ethnography and which - if interpreted according to its own mentality and logic - will facilitate understanding of the broader social and political processes taking place in Bashkortostan.

On the other hand, these narratives can also be considered etic since ethnographic science regards Kuzeev's works to be interpretive and academic. From this point of view, I already consider it important to distance myself from Kuzeev's analyses and to emphasise the constructivist and instrumentalist approach of my own analysis. The constructivist school that developed during the 1960s, hallmarked by Fredrik Barth, examines ethnicity with an approach entirely different from that of primordialist theories. According to constructivism, an ethnic group is not a given homogenous unit formed by its cultural constant, but the result of dynamically changing boundary building activity which can only be manifested through interaction with other ethnic groups. Constructivists regard this activity as ethnicity (BARTH 1969). In keeping with this approach, ethnicity is primarily manifest in social processes and its cultural features only make sense when examined in this light.

Barth's constructivism does not place a special emphasis on the role of culture in ethnicity and it is precisely this that the majority of critics find lacking. While agreeing with the constructivist view that ethnicity must be studied at the level of social life, Thomas Hylland Eriksen asserts that "Ethnicity is the enduring and systematic communication of cultural differences between groups considering themselves to be distinct" (ERIKSEN 2010:69). In Eriksen's interpretation, the intent to display culture and cultural features precedes and actually initiates social processes. In my opinion, setting an established order between the cultural and social processes of ethnicity is not worthwhile since the two are in a dialogue with one another, making it difficult to determine which takes priority over the other (or whether addressing this issue is important at all). The case of Bashkir identity examined in this study also provides a good illustration of why it is impossible to decide which of these processes gave rise to the other.

Using the expression groupism, Rogers Brubaker criticised the entire constructivist point of view, and not just with regards to methodology. Brubaker's instrumentalist concept argues that constructivism also tends to thinks in terms of homogeneous groups, using primordialist terminology when discussing ethnicity and ethnic conflicts and treating ethnic groups as "substantial entities to which interests and agency can be attributed" (BRUBAKER 2002:164). These conflicts can rather be called ethnicized or ethnically framed conflict, in the course of which a narrow strata tries to display its efforts as the interest of an entire ethnic group. In this way, "Ethnicity, race and nationhood exist only in and through our perceptions, interpretations, representations, categorizations and identifications. They are not things in the world, but perspectives on the world. These include ethnicized ways of seeing (and ignoring), of construing (and misconstruing), of inferring (and misinferring), and of remembering (and forgetting)" (BRUBAKER 2002:174). This is why I consider it important to stress that my study focuses on the interests and activities of a narrow political elite which sees Bashkir culture as the cause of all people who the same elite regards to be Bashkir, a perspective supported by Bashkir modes of ethnography and writing history. ${ }^{4}$

\footnotetext{
${ }^{4}$ Nevertheless, this does not mean that everyone truly identifies with this perspective, the analysis of which shall remain the subject of another study.
} 


\section{"THE RIGHT OF THE BASHKIR NATION" BASHKIR NATION-BUILDING DURING THE 1990s}

The current political situation in Bashkortostan has been determined to a great extent by the demographic and economic circumstances following the collapse of the Soviet Union. Maintaining its status as a republic within the Russian Federation has remained an important factor up to the present day, ${ }^{5}$ a fundamental criterion being the status of the Bashkir majority as a titular nation ${ }^{6}$ as opposed that of other peoples. On several occasions throughout the $20^{\text {th }}$ century, the Bashkir political elite has had to take decisive steps to ensure that those considering themselves Bashkirs did not become a minority among those proclaiming Tatar identity. The Tatar population has always had a threatening impact on the status of Bashkirs, not only due to its size, but also because of political support coming from Tatarstan. Tatar movements in Bashkortostan have demanded that Tatar forums, schools, media and political representation be given official status, but for Bashkirs the spontaneous processes of Tatarisation and assimilation also meant a continuous danger. Bashkir nationalism has primarily developed within this context and therefore can only be appropriately interpreted in this light.

The issue is basically rooted in the cultural, religious, linguistic and territorial proximity and permeability of the two ethnic groups, which the administrative structure of the Soviet Union only complicated further. As Russian imperial provinces were dismantled, more than two thirds of the mixed population living in territories along the border came under the authority of the Tatar Autonomous Soviet Socialist Republic, in which the benefits of belonging to a titular nation and a consistent language policy led to the rapid assimilation of those swinging between the two identities. However, the remaining third attached to the Bashkir Autonomous Soviet Socialist Republic were unable to feel an absolute connection with the Bashkir titular nation since the Bashkir literary language formed during the 1930s was the least compatible with the north-western Tatar dialect characteristic of the territory (GoRENBURG 1999:566). As a consequence, data from population surveys clearly reflect a Tatar speaking Bashkir group using the privilege of titular nation to assert its Bashkir identity while taking advantage of native language education and the close similarity of their dialect, preferring to retain Tatar as their mother tongue.

The policy of "one nation - one language" during the 60s and 70s, however, was an attempt to Bashkirise north-western groups in order to turn them into "true Bashkirs" as well. Even today, true Bashkirs are primarily regarded as those living in southern

\footnotetext{
${ }^{5}$ The Russian Federation comprises a total of 83 different subjects, each of which have different rights, constitutional sovereignty and authority to coordinate and control administration depending on their status.

${ }^{6}$ The concept of titular nation (titul'naâ naciâ) is connected to the political arrangement of the Soviet Union. Those regarded as titular nations were autonomous Soviet socialist units (republics, counties or territories) named after the prominent national group in the given territory. The language of the titular nation was the second official language after Russian, and its members enjoyed special rights in the sphere of politics, employment and education. While the special rights of titular nations were abolished in the wake of reforms during the 1980s, in Bashkortostan the benefits enjoyed by Bashkirs on the basis of ethnic differentiation (political status, distribution of financial resources, language usage etc.) remained after the political transition as well.
} 
and south-eastern areas, whose dialect served as the foundation for the Bashkir literary language and whose culture ethnographers also considered to be "more Bashkir" in a traditional sense. Using language as a tool of Bashkirisation, political circles continued to regard the north-western dialect as Bashkir rather than Tatar. Native language education was authorised on the basis of declared ethnic identity, which means that Bashkirs who had previously studied in Tatar had no choice but to take part in education using literary Bashkir or to choose Tatar identity, thereby depriving themselves of the special rights enjoyed by the titular nation. After these privileges were also cut during the Gorbechov era of the 80s, those living in north-western territories favoured retaining their mother tongue instead and declared themselves to be Tatars. As a result, the census taken in 1989 indicated that they comprised $28.5 \%$ of the population, with the Bashkir population at $22 \%$. Moreover, after the union collapsed, the north-western territories demanded total autonomy and secession from the republic (GORENBURG 1999:570-574).

This significantly limited opportunities for national and political independence when the new republic of Bashkortostan was established in 1993. While the political elite in Tatarstan strove to establish a new, sovereign Tatar state on the basis of an obvious Tatar majority, Bashkortostan was forced to search for a fundamental base that was also capable of legitimising its Bashkir minority in a leading role. As a consequence of this process, the new constitution declared the multi-ethnic (mnogonacional'nyj) composition of the population in Bashkortostan while simultaneously asserting the inalienable rights of Bashkirs to seek autonomy based on historical precedents and several centuries of territorial possession (Konstituci RossijsKoj Federacir 2015). The multi-ethnicity declared in the constitution directly resulted in a multilingual state, which meant that two official state languages existed alongside other acknowledged native tongues (ZAMÂTIN 2012:23): Russian and Bashkir, the latter being a manifestation of Bashkortostan's right to autonomy (RESPUBLIKA BAŠKORTOSTAN, ZAKON O ÂZYKAH NARODOV RESPUBLIKI BAŠKORTOSTAN 2015).

The Bashkir nation has also attempted to assert its political control through quotas and extended privileges, citing that its failure in elections behind Russians and Tatars is due to its minority status whereas Bashkirs enjoy a special right to control the territory and its population by way of their indigenous status. The compulsory ratio of Bashkirs in the parliament, in government agencies and in legislative committees was set at $50 \%$, and it has also been stipulated that only Bashkirs can represent the republic in the national chambers of the federal Duma (GoRENBurg 2006:98). Presidents are expected to have perfect knowledge of the Bashkir language, and so it is no surprise that the first head of state in Bashkortostan was also of Bashkir origin, Murtaza Rahimov, a "true" Bashkir from the southern territories who held the post for almost two decades. Rahimov, who had acquired considerable economic knowledge and an extensive network of contacts through his days in the oil industry, quickly recognised that the outstanding economic potential of the republic could serve not only as a possible foundation for national sovereignty, but also as one of the most important elements of nation-building. During the 1930s, Bashkortostan was counted as the largest oil producer in the Soviet Union, and although the significance of this decreased as the century progressed, the industry was expanded with oil refinement, petroleum production and petro-chemical research. With regards to its mineral resources, the territory is rich in copper and iron ore, but also boasts sites containing natural gas, gold, and coal. These characteristics provided a strong foundation for economic stability in Bashkortostan. In 1992, for example, the average income per 
person was 35,500 RUB, ${ }^{7}$ ranking the republic in fifth place within Russia (GoRENBURG 2006:22). Among other things, this situation resulted in Bashkortostan being able to retain $70 \%$ of the income derived from exports, allowing it to become one of the most financially and economically independent republics in the federation (GORENBURG 1999:253).

On the other hand, this income was not equally invested, at least not in economic terms. A significant portion of industrial and infrastructural development was concentrated in the southern territories, where the majority of the population is comprised of the previously mentioned "true" Bashkirs. In this sense, being Bashkir also meant special advantages in the sphere of employment, even though this was not possible according to the law. Bashkir cultural development and initiatives could also rely on financial support from the government e.g. the "Ural" Bashkir National Centre, which was quickly able to acquire its own building, conference room, vehicles and computers when it was established in 1989 (GORENBURG 2006:60), and government funding has been and continues to be used for the promotion of Bashkir language and culture.

This economic and cultural support is already providing suitable assistance for the reinforcement of Bashkir social solidarity as well. The majority of such initiatives have been organised and spread along the lines of Bashkir clan networks based on kinship, and this filter has inhibited any outsiders or resisters from infiltrating the ranks of activists in the movement (GoRENBURG 2006:59). Although prohibited during Soviet times, a tightly observed sense of clan belonging within families nevertheless meant a common identity, social bond and trust which easily mobilised the majority of Bashkirs. These are the initiatives and movements which led to emergence of Šäžärä Bajramy in 2006 the national Family Tree celebration officially supported by the government, which has become an important tool in Bashkir nation-building strategies in a newer attempt to Bashkirise the population in the north-west.

\section{"WE MUST NOT FORGET" THE FAMILY TREE FESTIVAL AS A TOOL OF BASHKIRISATION}

The presidential order of 2006 stipulated the compulsory annual organisation of the Family Tree Festival throughout the entire territory of Bashkortostan, which meant that celebrations took place not only in areas with a Bashkir majority, but in every single municipality, regardless of ethnic affiliation. In spite of the above, the presidential order as well as several methodological reference books and the media do not regard Family Tree Day as a national celebration, but as a Bashkir ethnic festival. While the tracking of ancestral origin is not regarded as a uniquely Bashkir trait, its criteria have clearly adjusted to Bashkir traditions, particularly encouraging depictions of the patrilineal lineage and as well its tribal and clan ${ }^{8}$ affiliations and attributes (tamga, tree, bird, battle cry). The Family

\footnotetext{
${ }^{7}$ In 1992, one USD equalled 55-57 RUF, which means that 35,500 RUB counted as approximately 620-645 USD (Archive of Bank of Russia, 2015). The average income per person in 2010 was a total of 16,400 RUB, which then totalled roughly 540 USD ( 1 dollar $=30.5$ rubel - Exchanges Rates UK, 2015), which ranked Bashkortostan fifteenth within the federation (Srednemesâčnaâ zarabotnaâ plata regionov RF za 2010 god, 2015).

${ }^{8}$ See further below regarding usage of the terminology.
} 
Tree competition and modes of celebration also follow traditions that are considered to be Bashkir, which contend that "no Bashkir celebration can be conducted without a competition" (BURAKAEVA 2010:45). Officially, the celebration was preceded by a local family tree competition in which all of the family trees prepared in the given village or city were evaluated prior to the national festival, where only the winners were displayed. Of course this was not always possible in smaller villages which produced far fewer family trees, and so all of the entries were then displayed during the festival as well. Family trees were primarily judged on the basis of their "depth", meaning how many generations the genealogy was able to cover, which could also be supplemented with essential data and family narratives. Important information included the citizenship and personal data of family members, their religious and political affiliation, their level of schooling and social circumstances as well as their appearance and details concerning their state of health. Competitors were especially encouraged to research and present any particularly talented members of their families. The national festival then entailed the presentation of family trees specifically belonging to famous historical figures from various municipalities.

The government provided a suitable structural and financial background for all of the above, ensuring cooperation between the Ministry of Culture, the Bashkortostan Academy of Sciences and registry offices. In addition, research centres were established throughout the entire republic, where all relevant local materials were archived and made available to the public. Computer databases were set up for these centres, which allowed public access to the materials on the internet along with reference guides and source materials in order to make research easier for laymen. Therefore, numerous materials can also be accessed on the homepages of archives in Bashkortostan (ARHIVY BAŠKORTOSTANA 2015). There was also a strong government effort to incorporate genealogy in the educational program, and this has remained an integral part of the curriculum to this day. The development of skills related to constructing genealogical depictions covering three generations has even become a part of studies at the kindergarten level, which also serves to provide a pedagogical method for conveying the family as a fundamental value. Pupils engage in a comprehensive study of genealogy within the framework of the subject called Istoriâ i kul tury Baškortostana, meaning the history and culture of Bashkortostan, introduced during the early 1990s, and also within the context of compulsory Bashkir language lessons, during which they prepare their own family trees. Naturally, local, municipal and national competitions were announced for students as well, giving them the opportunity to display one or two richly illustrated family trees or to display their genealogical depictions of famous individuals born in the Bashkir homeland.

This broad and carefully structured national program has aimed to achieve numerous goals. The most important point mentioned in the presidential order was that genealogy not only facilitates the accumulation and transfer of knowledge in connection with the family, but also plays an important role in reinforcing the bonds of kinship while helping to ensure generational continuity and health. The latter is considered important in order to prevent intermarriage and the genetic problems it causes, stressing adherence to seventh generation exogamy. According to the order, in addition to the study of families and the clan as well as the collection of family legends and anecdotes, genealogy also enriches the history of the homeland, the revival of family tradition being a way to foster the aesthetic, moral and spiritual development of future generations. The program has also fulfilled somewhat of a propagandistic role, with the revitalisation of Bashkir national 


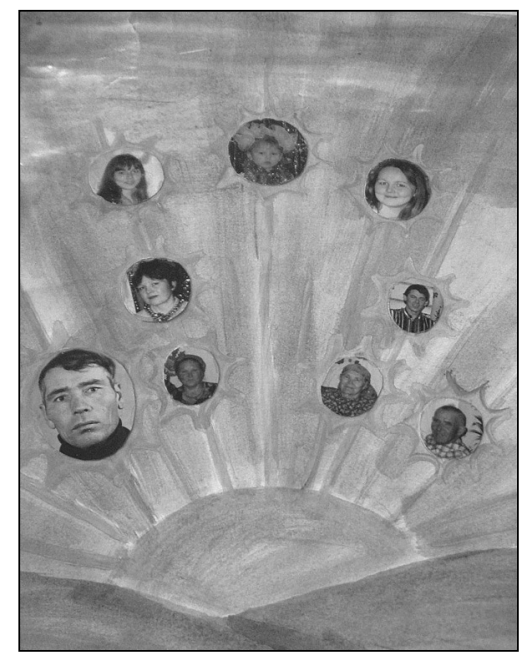

Figure 1. Family tree of a kindergardener, Novye Tatyšly, 2012. (Photo by Boglárka Mácsai)

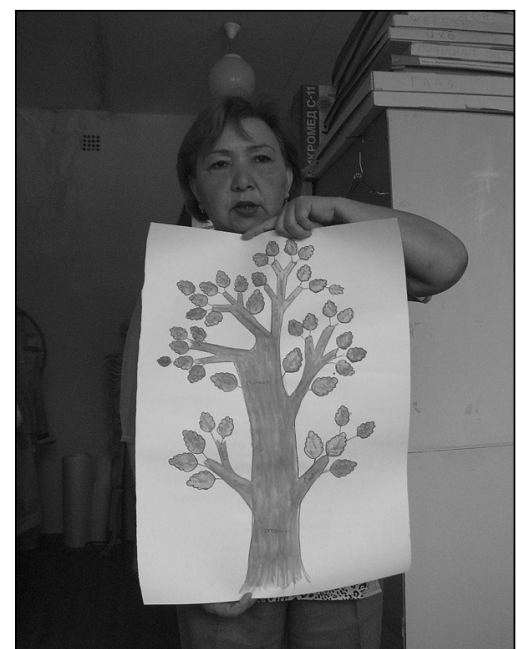

Figure 2. Family tree of a student in the elementary school, Verhnie Tatyšly, 2012. (Photo by Boglárka Mácsai)

traditions and customs as its explicitly expressed goal along with the popularisation of Bashkir national games (ZAKONODATEL'sTvo RossiJSKOJ FEDERACII 2015).

In other words, while the program has involved the entire population, with attempts to de-ethnicise it at certain points along the way, it was rather designed to facilitate Bashkir national unity on the basis of Bashkir traditions, as manifested in the texts published in methodological reference books:

The history of Bashkir tribes and clans is the history of the Bashkir nation. (...) Although no tribes exist today in the classic sense, many Bashkir people continue to remember their ethnic roots. They are aware of their tribal history and the history of their clan. They have thus preserved the memory of their ancestors. We must not forget that the people which remembers its own historical roots will never be small and will never be lost. (ÂNGUŽIN 2010:9)

Genealogy has proven appropriate for satisfying this goal in several aspects. It looks back on a significant past. Its tradition, even if curtailed, has remained strongly in memory. It has given a well-defined and tangible rendition of the Bashkir nation and has already provided a strong academic foundation for research on tribes and various clans.

This academic foundation, and especially its kinship terminology and categorisation, is largely due to the work of historian-ethnographer Rail Kuzeev, who writes the following in his book entitled Origins of the Bashkir People:

The Bashkir clan-tribal system [rodo-plemennaâ sistema] could be divided into three parts: tribe [plemâ], clan [rod] and lineage [rodovoe podrazdelenie]. Nevertheless, this terminology can only be applied under certain conditions. While it serves to express the structure of the Bashkir clan-tribal system, it does not include socio-economic content, which is usually associated with these terms in a classic sense. (KuZEev 1974:76) 
In light of the above, Kuzeev's interpretation of these three concepts in the course of discussing Bashkir social structure entailed the following. He defined lineage as an exogamic unit of related families descended from a distant common ancestor. Relatives with common names and tamgas living in separate places in the same village cooperated economically and took part in each other's rituals. Clan was comprised of more distantly related lineages, who were presumably descended from a presumably famous or heroic ancestor. These also possessed common names and tamgas, which were further varied according to lineage. In most cases, they were characterised by exogamy and a common territory of settlement. Tribal organisations were comprised of several unified clans, which, according to Kuzeev, were also bonded by kinship, not only due to common ethnonyms and territory, but also because of common attributes, such as tamgas, species of trees and birds, or war cries symbolic of the tribe. Tribes also operated as political entities, given the presence of elder councils and public assemblies (KuZEev 1974:76).

This categorisation proved to be an important tool in the Bashkirisation of northwestern groups, in which the last phase of Bashkir ethnogenesis as described by Kuzeev played a key role. According to Kuzeev, allies of tribes migrating to and settling in the south-western region of the Ural Mountains during the first half of the $2^{\text {nd }}$ century provided the basic foundation for the formation of the Bashkir ethnos. He regarded the $15^{\text {th }}$ century migration of clans separating from these tribes and relocating to the northwestern territory of Bashkiria in the service of the Kazan Khanate as the closing phase of the ethnogenesis, indicating kinship with south-eastern tribes with the help of family trees discovered in north-western areas (KuzEev 1974:319). In other words, the Bashkir identity of those living in the northwest was already no longer an issue for Kuzeev during the 1950s and 60s, certainly not in the genealogical sense.

Accession to the Russian Empire and the related consequences during the $16^{\text {th }}$ century proved to be a major turning point. The earliest of the surviving family trees are dated to this period. These not only render patrilineal genealogy going back upwards of ten or even fifteen generations, but were also supplemented with additional information: dates, inheritance data and narratives concerning various events. According to Kuzeev, this proves that the rapidly growing population was also forced to keep records in order to remember its ancestors and relatives, and also to ensure possession of territories and patrilineal inheritance following accession to the Russian Empire - the latter of which seems to be a more plausible explanation. This was especially important in the case of Bashkiria since the contract established with the Russians stipulated that the territory of Bashkiria could remain in the hands of indigenous people in exchange for military service, and the unity of family lands was also taken into account when administrative units, volost's, were established later on (KUZEEv 1960:6-14). ${ }^{9}$

According to local research, this is also the period to which the "authenticity" of Bashkirs living in the north-western part of Bashkiria can be traced. The issue of authenticity essentially involves deciding which cultural features can serve to make a distinction between Bashkirs and Tatars, and the changes taking place during the $16^{\text {th }}$ century were also significant from this perspective. The north-western territories quickly stepped on the path towards feudalism, which provided suitable conditions for a settled

\footnotetext{
${ }^{9}$ For a post-colonialist critique and further information on the role of volosts, see: MÉszÁRos 2013:5783.
} 
agricultural lifestyle taking place in the $15^{\text {th }}$ and $16^{\text {th }}$ centuries (KuzeEv 1960:14). By contrast, the majority of Bashkirs living in south-eastern areas continued their nomadic way of life up to as late as the $19^{\text {th }}$ century. In comparison to neighbouring ethnic groups, this divergent lifestyle was also clearly reflected in the summer landscape, in which herds of cattle and yurts defined the characteristic Bashkir existence. ${ }^{10}$ The costumes and material culture of those living in the border territories of the northwest (which researchers suggest were mainly characterised by the use of birch, straw and reeds) also clearly showed the influence of Tatars as well as the impact of interethnic relations maintained with other groups living in the area (e.g. Udmurt, Chuvash and Mari) while the population living in southern areas upheld the most typically Bashkir traditions by continuing to preserve traditional leather craft and wearing costumes distinct from those of other ethnic groups in the region. With regards to family trees, fieldwork in the south yielded far more in the way of collected samples, which Kuzeev saw as newer proof of the continuous practice of tradition. In any case, the abundance of material enabled more thorough and detailed research in these areas. As I have already mentioned above, the southern dialect of the Bashkir language was the one that differed the most from the Tatar language, and this also counted as a contributing factor when judging "authenticity" later on. That is to say that Bashkirs living in territories adjacent to Tatars adapted to the culture of their neighbours in several ways (and the same is true in reverse), while the denser concentration of Bashkirs in the southern and south-western regions was characterised by fewer interethnic relations, and so was therefore less influenced by Tatars. This gave their culture a stronger, more Bashkir character, which proved to be more conducive to creating a distinct policy of ethnic identity and nation-building.

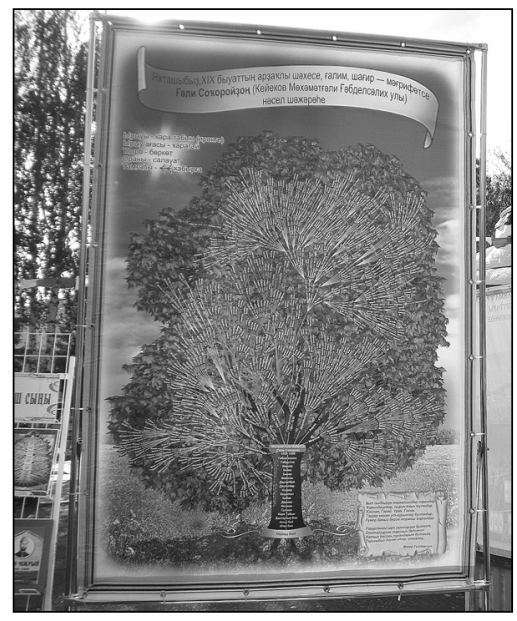

Figure 3. Gali Čokroj family tree, Karmashkaly, 2013. (Photo by Boglárka Mácsai)

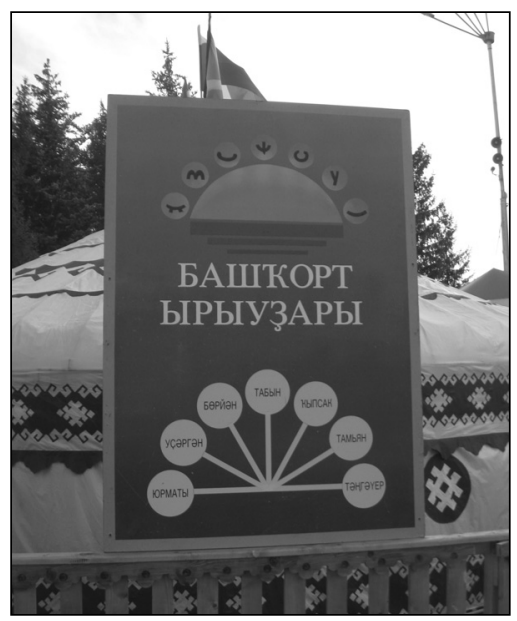

Figure 4. The seven Bashkir tribes, Karmashkaly, 2013. (Photo by Boglárka Mácsai)

\footnotetext{
${ }^{10}$ The famous Bashkir dairy products of today cannot be attributed simply to centuries of animal husbandry and milk processing either, but also to the unique farming of vegetation on the southern steppe and its high concentration of vitamin and mineral content, which is not so typical of the northern areas.
} 
The problem developed in the new, ethnically based administrative structures of the Soviet Union and in ethnic categories of population surveys during the $20^{\text {th }}$ century, which culminated prior to the collapse of the Soviet Union in the results of the 1989 census mentioned above. The Tatar majority also caused significant problems in the course of developing nation-building and minority policies, which President Murtaza Rahimov took great care to alleviate. During the next census in 2002, the government placed a serious emphasis on the Bashkirisation of north-western population, which was not manifested in media propaganda, but also in the falsification of the results. This succeeded in reversing the earlier ratio, putting the number of Bashkirs at $30 \%$, with the number of Tatars representing only 24\% (VSEROSSIJSKAÂ PEREPIS' NASELENIÂ 2002; GODA 2009). In several places, the propaganda was so successful that people in the northwest became completely confused as to their identity. Even today, many describe themselves as half-Bashkir and half-Tatar, but in the census of 2010, they tended to choose the Bashkir ethnic category. ${ }^{11}$

This tendency was largely assisted by the development of the Family Tree Festival as well. Methodological supplements and databases created on the basis of Kuzeev's research specifically stipulate that north-westerners be categorised among tribes which Kuzeev already identified during the 1960s as having ancestral, and therefore authentic, Bashkir roots among south-eastern clans. ${ }^{12}$ Given that local historical research has pervaded the entire program and practically every level of education, lay researchers responsible for local knowledge as well as entire generations of youth have acquired genealogical "evidence" of their ethnic affiliation, which could also have strong impact on the assertion of their identities in the future.

\section{"TWO BRANCHES OF THE SAME TREE" THE FAMILY TREE FESTIVAL AS A RUSSIAN TRADITION}

The Family Tree Festival provided flexible solutions in answer to the ethnic processes and political processes taking place in Bashkortostan, which could also be adopted by other ethnic groups in the republic and even Russia itself. To begin with, the program was organised in the framework of the $450^{\text {th }}$ anniversary of Bashkiria's voluntary accession to Russia (ZaKonodatel'stvo Rossisskoj Federacir 2015), which in 2007 was designed

\footnotetext{
${ }^{11}$ I collected relevant data in the course of my fieldwork in 2012 and 2013 in the municipality of Tatyšly (in the northwest territory of Bashkortostan). Procedures used here in 2002 were so successful that two thirds of people who had previously considered themselves Tatars were registered as Bashkir. The media propaganda also convinced an acquaintance of mine who was known to regard himself as Udmurt that the primary interest of the republic was to increase the number of Bashkirs, which led her to register as Bashkir too. Her case can actually be considered an exception since the majority of people in the municipality at the time still talked about Tatars in reference to locals whom the government regarded as Bashkir. Another illustration of the difference between discourse in local and state-supported research was the case of an ethnographer of Udmurt descent who expressed surprise when explaining that according to researchers in the capital, Tatar locals who she had known since childhood were in fact Bashkir.

${ }^{12}$ In this example, the winner of the national competition from Tatyšly municipality, the family tree of Bashkir-Tatar poet Gali Čokroj (1828-1889) also displays attributes of the iräkte tribe previously belonging to the kara tabyn tribe which had migrated from the south.
} 
to commemorate centuries of Russian-Bashkir coexistence since 1557 in the form of grandiose festivities and projects. ${ }^{13}$ Otherwise called "450 years together with Russia", the series of events was presumably encouraged for financial reasons as well since the federation also contributed funding to the organised programs.

Even so, affiliation with the Russian Federation was not explicitly placed in the foreground of the Family Tree program, which made a much stronger attempt to integrate within the trends and standards of state education. Until 2007, the Russian Federation delegated $60 \%$ of the education structure to the state, $30 \%$ to various federal subjects and 10\% to local institutions (VAILLANT 2005:223). The 30\% allowed Bashkortostan to introduce the subject entitled "History and Culture of Bashkortostan", initiating the acquisition of learning material dealing with local and regional subjects, and the incorporation of genealogy in the curriculum, meaning a large portion of the educational dimension in Bashkir nation-building policy. This education standard was practically abolished in 2007 so as to standardise federal education, but protest from Bashkortostan and Tatarstan resulted in some concessions in the curricula of the two neighbouring republics - which meant that the previously introduced subjects could remain in addition to the compulsory number of lessons (ZaMÂTIN 2012:25).

At the same time, the new standard also meant the compulsory inclusion of afternoon extra-curricular activities in six categories: intellectual preparation for subject-specific competitions (intellektualnoe), moral instruction ensuring appropriate citizenship (nravstvennoe), instruction designed to increase patriotic sentiment among students (patriotičeskoe), physical education promoting fitness and a healthy lifestyle (fizičeskoe), art-aesthetics to satisfy students' creative desires (hudožestvenno-èstetičeskoe), and training design to encourage enthusiasm for work and its accomplishment (trudovoe). In the course of application, however, the line between these categories is often blurred, and it depends on the given school as to which form of training receives greater emphasis. In any case, moral and patriotic training are completely suited for genealogy, even if this is not immediately apparent.

Moral and patriotic training are regarded as tightly interconnected sectors of education, which are primarily manifested in citizenship training (MÁcsAI 2014b). The main space for this in schools is the so-called school museum, which in a narrow in sense involves the presentation of national history and famous figures, being an exhibition space central to the serious Russian tradition of kraevedenie (MácSAI 2014a). Following the Family Tree festivities, the family trees of famous individuals and notable villagers are put on display in school museums, in part so that locals can also observe them and partly as a tool of illustration to foster the acquisition of skills in connection with family tree depiction and kraevedenie.

For lack of a better expression, the term kraevedenie is usually translated as local history, but I would prefer to use the original term in light of its multi-layered and complex

\footnotetext{
${ }^{13}$ As in the case of several neighbouring republics, the expression "voluntary accession" (dobrovol'noe prisoedinenie) is an official term which completely ignores military resistance by indigenous peoples against Russian conquerors in the $15^{\text {th }}$ and $16^{\text {th }}$ centuries.
} 
meaning. ${ }^{14}$ The expression rodnoj kraj should also be noted here. Its meaning can best be illustrated with the word homeland, which can refer to a village, a municipality or to Bashkiria in its entirety, but it can also function as a cognitive category, which sets linguistic, cultural and ethnic boundaries for the homeland rather than geographical ones. The expression "little homeland" (malaâ rodina) can also be used as a synonym for kraj and rodnoj kraj, a verbal association suggesting a part-whole affiliation with the larger homeland (Rodina), which also sheds light on the essence of kraevedenie. As such, kraevedenie strives for the research and conservation of local subject matter established by state, regional and local institutions and players in addition to its institutionalised transfer from generation to generation, including all branches of academic science as well as local references placed within the framework of official interpretation controlled by the state. In other words, just as the little homeland is included in the larger homeland, local content cannot be interpreted without knowledge of broader contexts.

It is precisely due to this embeddedness that the history of kraevedenie is not devoid of political influence either. The academic sphere formed during the $18^{\text {th }}$ century was already regarded as a popular occupation among researchers by the beginning of the $20^{\text {th }}$. By the 1930s, however, the work of those representing kraevedenie, who believed in cultural and economic diversity, was becoming a problem for Soviet powers. Opposition to Stalinist collectivism and institutional uniformisation led to the persecution of kraeveds and the closure of numerous museums, after which science was put under central control. While museums retained their geographical, archaeological and ethnographic content, a new emphasis was placed on local revolutionary movements, the history of the school, and the history of industry and agriculture. Following World War II, all of this was supplemented with portraits of war heroes and soldiers who came from villages, expanded over time by the stories of newer and newer warriors (Stroev 1974).

Beginning in the 1950s, the content of exhibitions was essentially determined by this theme, but due to the essence of kraevedenie, other local and regional themes could also be added at any time. It was practically as a result of the latter that the Family Tree program found its place within the context of kraevedenie - and also within the context of a broader Russian tradition. Presumably due to the Bashkirisation of northwestern groups, it was not only the Bashkir population who were obliged by the Bashkir government to take part in the program, but other ethnic groups as well, and so it also became necessary to find categories like family or cultural homeland, which were more neutral in terms of ethnic content. This is reflected nicely in the following quote, which handles genealogy as a far more universal value:

The aim of our work is embodied in manifestation of a richer spiritual and moral strength among our nations and the residents of our district, in the revitalisation of the centuries-old patriotic foundation of our social and private lives, in the psycho-philosophical reinforcement of our children and adolescents, and in our attempts to carefully redirect our children towards the stream of authentic culture in its true spirit and beauty. I believe that every human and every

\footnotetext{
${ }^{14}$ The term is derived from a Kraj word that also has multiple meanings. It partly designates a relatively smaller geographic territory, such as an area or region with natural borders, but it can also refer to the borders of a specific territory, i.e. "the ends". In addition, it also refers to official or semi-official Kraj administrative units comprising the provinces of the Russian Empire from the end of the $18^{\text {th }}$ century to the beginning of the $20^{\text {th }}$, for example Altaj Kraj, Perm Kraj or Kamchatka Kraj.
} 
nation must understand their place in the world, in nature and among other humans and nations, which is impossible without knowledge of history, culture, and the customs of our Homeland [Rodina] and our family. Every person is tightly connected to the present, future and past of their Homeland [Rodina] and their family. (KunAKKILDina 2010:73)

It was in this manner that exhibitions on local history in Bashkortostan came to incorporate family trees as a unique display of local and ethnic social history, which could then be easily connected to sections presenting narratives about local village heroes or local ethnic groups. In this way, they also could become an integral part of ethno-local identity policies. Organisers of Family Tree Festivals consciously strove to approach the traditions of kraevedenie since the competitions were enriched by local exhibitions, excursions, conferences and roundtable discussions, and by the publication of methodological reference guides that continuously emphasised the importance of knowledge about and love for the homeland. Consequently, the program became compatible with other Russian programs emphasising the value of local identity, e.g. the project entitled Our Homelanders (Zemlâki), announced in 2010 by the Unified Russia Party (Edinaâ Rossiâ), which means that participants in the competition searcing for the greatest villagers were also able to utilise the results of genealogy since the majority of entries in the competition dealing with migrated heroes also contained their own genealogies.

Last, but not least, the Family Tree Festival was also easily adapted to the Russian Year of the Family in 2008 (GoD Sem's 2008). ${ }^{15}$ Education had originally regarded the love of family as an important aspect of training, with the goal of encouraging family pride and respect for parents among young people as well as developing their interest in family history and traditions (KUNAKKILDINA 2010:73-74), but the transfer of family values supported by state propaganda became increasingly important:

We do not know our roots well, which is our poverty. Family pride and an interest in our family tree - these are two branches of the same tree. We must not live without knowing our kinship, and we must not study the history of the Homeland and of the family separately. Family memory plays an important role in education promoting clan pride. Through the history of family, every child is learning learns the entire history of Russia. Text for kindergarten presentation, collected: Novye Tatyšly, 22 May 2012.

As can be seen, the Family Tree Festival was not merely a solution to for nationbuilding and ethnic problems in Bashkortostan, but was also sensitive to the complex alliance and cooperation with Russia. Within the framework of kraevedenie, it fit perfectly within the traditions of Russian education and also fulfilled the task of moral training by communicating the values of family and patriotism.

\footnotetext{
${ }^{15}$ The population of the federation declined with five million according the 2006 census, thus the government implemented several initiations to reverse the process. Maternity grant after the birth of the second child has been introduced from January 1, 2007 This is a remarkable amount of one-time sum (250 thousand RUB in 2007; 430 thousand RUB in 2014) to be spent on construction, health care or tuition fees. The grant seems to give inevitable impetus in demography. Thereafter 2008 was announced the "Year of Family" when several complex educational and media programs were run.
} 


\section{"SOLIDIFYING THE SPIRITUAL STRENGTH OF THE NATION" CONCLUSION}

This study has sought to find an answer to the issue of how a revived tradition can serve political interests that are simultaneously attempting to satisfy the demands of nationbuilding based on ethnicity and the demands of affiliation with a larger multi-ethnic nation. First, I examined the utilisation of tradition in support of attempts by an ethnic nation to gain power and autonomy through a conscious program of re-ethnicisation aimed at certain ethnic groups. This was followed by an indication of how a tradition that is fundamentally regarded as ethnic can be in a broader non-ethnic context, and how it can legitimise its place thereof. In this way, I managed to show how seemingly contradictory strategies for the use of this tradition can effectively complement one another in reality. Thanks to encouragement by the government, the Family Tree Festival was able to continuously fulfill this role all the way up to 2010, when Rustem Hamitov became the new President of Bashkortostan, after which nationalist policies were forced into the background. Among other things, this new direction was due to the fact that the president was from one of the north-western municipalities in the Bashkirised part of the republic. While Hamitov clearly expressed his rejection of the Bashkirisation and fraud that took place in the course of the 2002 census (Hamitov 2011), the census of 2010 only reflected this to a minimal extent. ${ }^{16}$ The Family Tree Festival lost its compulsory requirements, but funding was not completely abolished and the established structures and educational programs were retained. If not in every village, the family tree tradition continues to exist today, having been deeply rooted in Bashkir consciousness and also in the preservation of kraevedenie, and thus has the "Family Tree Festival solidified the spiritual strength of the nation [naciâa]". (Šaripova 2010:47)

\section{REFERENCES CITED}

Archive of BanK of Russia

2015 http://cbr.ru/currency_base/OldDataFiles/USD.xls (accessed February 2, 2015)

ARHIVY BašKoRTOSTANA [Archives of Bashkortostan]

2015 http://www.gasrb.ru/ (accessed February 5, 2015)

ÂNGUŽIN, Rim

2010 Kratkaâ istoričeskaâ spravka o šežere [A Short Historical Note on FamilyTree]. In Asadullina-Ibragimova, Nuriâ Išmuhametovna (ed) $V$ pomo $\hat{s}$ organizatoram prazdnika Šäžärä Bajramy [A Guide for the Organizers of the Holiday „Family Tree”], 6-10. Ufa: Delovaâ dinastiâ.

\footnotetext{
${ }^{16}$ The most recent census indicated the Bashkir population at $29.5 \%$ and the Tatars at $25.5 \%$. (This ratio was $30 \%-24 \%$ in 2002.) While the national results did not show a large difference, the results of the census in the Tatyšly municipality clearly reflected the current political attitude towards the issue of north-western Bashkirs. In 1989, the ratio of Bashkirs was $54 \%$ while that of Tatars was $21 \%$. In 2002 , this difference was increased to $70 \%$ and $5 \%$ respectively. The change in 2010 brought the number of Bashkirs back to $60 \%$ while the lost $10 \%$ returned to the Tatars, who then comprised $15 \%$ of the population in the municipality.
} 
BARTH, Fredrik

1969 Introduction. In BARTH, Fredrik (ed) Ethnic Groups and Boundaries: The Social Organization of Culture Difference, 9-37. Oslo: Universitetsforlaget.

BROMLEJ, Julian

1976 Etnosz és néprajz [Ethnos and Ethnography]. Budapest: Gondolat Kiadó.

BRUBAKER, Rogers

2002 Ethnicity Without Groups. European Journal of Sociology 18(2):163-189.

BuRAKAEVA, Mar'âm

2010 Ne zapâtnaj svoj rod ili rekomendacii po provedeniû prazdnika Šäžärä Bajramy [Do Not Taint Your Clan or Recommendation on Organisation of Holiday "Family Tree"]. In Asadullina-Ibragimova, Nuriâ Išmuhametovna (ed) $V$ pomoŝ organizatoram prazdnika Šäžärä Bajramy [A Guide for the Organizers of the Holiday "Family Tree"], 42-46. Ufa: Delovaâ dinastiâ.

ERIKSEN, Thomas Hylland

2010 Ethnicity and Nationalism. Anthropological Perspectives. New York: Pluto.

EXCHANGE RATES UK

2015 http://www.exchangerates.org.uk/RUB-USD-31_12_2010-exchange-ratehistory.html (accessed February 2, 2015)

FILIPPOV, Vasilij

2010 Sovetskaâ teoriâ ètnosa. Istoriografičeskij očerk [Soviet Theory of Ethnos. Historical Essay]. Moskva: Institut Afriki RAN.

God SEM'I [Year of the Family]

2008 http://www.semya2008.ru/ (accessed July 29, 2014)

GorenburG, Dmitry

2006 Minority Ethnic Mobilization in the Russian Federation. Cambridge: Cambridge University Press.

1999 Identity Change in Bashkortostan. Tatars into Bashkirs and Back. Ethnic and Racial Studies 22(3):554-580.

1999 Regional Separatism in Russia. Ethnic Mobilization or Power Grab? EuropeAsia Studies 51(2):245-274.

2004 Tatar Identity. a United, Indivisible Nation? Manuscript http://www.scribd. com/doc/130618530/Tatar-Identity-A-United-Indivisible-Nation-DmitryGorenburg-Harvard-University-July-19-2004-pdf (accessed March 4, 2013)

GumiLjOV, Lev

1975 Tanulmányok az etnoszról [Studies on Ethnos]. Budapest - Szolnok: MTA Néprajzi Kutatócsoport - Damjanich János Múzeum.

HAMitov, Rustem

2011 Iskustvennaâ respublika, fal'šivaâ perepis' [Artificial Republic, Falsified Census]. Ufimskaâ žurnal December 19. http://journalufa.com/2204iskusstvennaya-respublika-falshivaya-perepis.html (accessed June 12, 2012)

KNORRE, Boris

2008 Marijskoe âzičestvo pod natiskom New-Age [Mari Paganism during the New Age]. The Russian Review ten. http://www.keston.org.uk/russia/articles/ rr31/02mari-paganism.html (accessed February 5, 2015) 
KNORRE, Boris - Elena Konstantinova

2010 Marijskaâ narodnaâ vera i bor'ba mari za nacional'nye interesy v poslednee 10-letie [Mari Vernacular Belief and Mari Fight for National Interests in the Last 10 years]. The Russian Review 42. http://www.keston.org.uk/_russianreview/ edition42/03-mari-from-knorre.html (accessed February 5, 2015)

KonstituciI Rossisskoj FederaciI [Constitutions of the Russian Federation]

2015 Konstituciâ Respubliki Baškortostan [Constitution of the Republic of Bashkortostan] http://constitution.garant.ru/region/cons_bashkor/ chapter/1/\#block_700 (accessed February 1, 2015)

KUNAKKILDINA, R. A.

2010 Letopis' moej sem'I [Chronicle of my Family]. In Asadullina-Ibragimova, Nuriâ Išmuhametovna (ed) V pomôs organizatoram prazdnika Šäžärä Bajramy [A Guide for the Organizers of the Holiday "Family Tree"], 73-85. Ufa: Delovaâ dinastiâ.

KuZeEv, Rail

1960 Baškirskie šežere [Bashkir Family-Trees]. Ufa: Baškirskoe knižnoe izdatel'stvo.

1974 Proishoždenie baškirskogo naroda. Ėtničeskij sostav, istoriâ rasseleniâ [The Origin of the Bashkir People. Ethnic Composition, History of Settlement]. Moskva: Nauka.

MácsAI, Boglárka

2014a A Kis Haza. Iskolamúzeumok Bashkortostanban [Little Motherland. SchoolMuseums in Bashkortostan]. In BöHM, Gábor - FedELEs, Tamás (eds) Mesterek és Tanitványok. Tanulmányok a bölcsészettudományok területéröl, 35-54. Pécs: Pécsi Tudományegyetem.

$2014 \mathrm{~b} \mathrm{Az}$ új lendület - Állampolgári-hazafias nevelés Oroszországban [A New Momentum: Civic-Patriotic Upbringing in Russia]. Pro Minoritate Autumn:148-167.

MÉszÁros, Csaba

2013 Tekintély és bizalom. Kultúra és társadalom két szibériai faluközösségben [Respect and Trust: Culture and Society in Two Siberian Village Communities]. Budapest - Pécs: MTA BTK Néprajztudományi Intézet - PTE BTK Néprajz Kulturális Antropológia Tanszék - L’Harmattan.

RESPUBliKa BašKortostan, ZAKON O ÂZYKAH NARODOV RESPUBLIKI BAŠKORTOSTAN [Republic of Bashkortostan, Law on Languages of Peoples of Republic of Bashkortostan] 2015 http://www.morb.ru/documents/rb/216.pdf (accessed February 01, 2015) ŠARIPOVA, Farida

2010 Kto ty est'? [Who are you?] In AsadulLINA-IBRAGImova, Nuriâ Išmuhametovna (ed) V pomoŝ organizatoram prazdnika Šäžärä Bajramy [A Guide for the Organizers of the Holiday "Family Tree"], 47-48. Ufa: Delovaâ dinastiâ.

SREDNEMESÂČNAÂ ZARABOTNAÂ PLATA REGIONOV RF ZA 2010 GOD [The Average Monthly Wage of Regions of the Russian Federation in 2010]

2015 Archived: http://www.webcitation.org/67Et2bR1L (accessed February 2, 2015) Stroev, Konstantin

1974 Kraevedenie [Local History]. Moskva: Nauka. 
VAILlant, Janet G.

2005 Civic Education in a Changing Russia. In EkLof, Ben - Holmes, Larry E. - Kaplan, Vera (eds) Educational Reform in Post-Soviet Russia, 221-247. London - New York: Frank Cass.

VSEROSSIJSKAÂ PEREPIS' NASELENIÂ 2002 GODA [All-Russian Population Census 2002]

2009 www.perepis2002.ru (accessed September 1, 2009)

ZaKonodatel'stvo RossiJskoj Federaci [Legislation of the Russian Federation]

2015 Postanovlenie o provedenii narodnogo prazdnika Šežere Bajramy v respublike Baškortostan [Enactment on Organistaion of National Holiday "Family Tree" in the Republic of Bashkortostan]. http://lawsrf.ru/ (accessed February 10, 2015)

ZAMÂTIN, Konstantin

2012 The Education Reform in Russia and its Impact on Teaching of the Minority Languages: An Effect of Nation-Building? Journal on Ethnopolitics and Minority Issues in Europe 11(1):17-47.

Boglárka Mácsai is a junior research fellow at the Department of Finno-Ugric and Historical Linguistics, Research Institute for Linguistics, Hungarian Academy of Sciences. She carried out fieldwork in Bashkortostan (Russian Federation). Her main fields: ethnicity, nationalism, political anthropology, educational anthropology. Email-address: boglarka.macsai@gmail.com 